\title{
PERINTISAN MODEL PEMBELAJARAN TERINTEGRASI TIK DI DAERAH TERDEPAN, TERLUAR, TERTINGGAL, DAN PERBATASAN
}

\author{
Pilotting of ICT Integrated Learning Model in the Borderline, \\ Outer, Left and Frontier Areas
}

\author{
SUDIRMAN SIAHAAN
}

Pemerhati bidang teknologi pendidikan. pakdirman@yahoo.com

\begin{abstract}
ABSTRAK: Kegiatan pembelajaran di sekolah-sekolah di daerah terdepan, terluar, tertinggal, dan perbatasan (3TP) pada umumnya belum tersentuh teknologi informasi dan komunikasi (TIK). Hal ini karena sekolah belum memiliki sumber tenaga listrik, sumber belajarnya terbatas, dan guru yang memiliki kemampuan memanfaatkan TIK dalam pembelajaran juga terbatas. Metode pembelajaran yang diterapkan guru masih yang bersifat konvensional. Pada tahun 2015, perintisan penerapan model pembelajaran terintegrasi dimulai dengan memilih 10 sekolah (5 SD dan 5 SMP) yang tersebar di 5 provinsi. Masalah yang menjadi fokus pembahasan di dalam tulisan ini adalah bagaimana sekolah-sekolah di daerah 3TP yang kondisinya serba terbatas dapat memulai penerapan model pembelajaran terintegrasi TIK. Tujuan penulisan artikel ini adalah untuk mendeskripsikan bagaimana para guru di sekolah-sekolah daerah 3TP melaksanakan perintisan penerapan model pembelajaran terintegrasi TIK. Kesimpulan hasil kajian adalah bahwa guru terlebih dahulu mempelajari dan memetakan konten pembelajaran digital yang tersedia dan yang dicari sendiri, mengintegrasikannya ke dalam Rencana Pelaksanaan Pembelajaran (RPP), mempersiapkan peserta didik untuk mempelajari konten yang akan dibahas di kelas, menerapkan model pembelajaran terintegrasi TIK, dan akhirnya melakukan evaluasi keterlaksanaan model pembelajaran sebagai upaya guru menyempurnakan model.
\end{abstract}

Kata Kunci: Teknologi Informasi and Komunikasi (TIK); daerah 3TP; pembelajaran.

ABSTRACT: Learning process at the schools in frontier, outer, left, and border (3TP) areas has not commonly been touched with Information and Communication Technology (ICT). It is because the schools have no power access, limited learning sources, and limited teachers with ICT competencies. The applied learning approach is still conventional. In 2015, integrated learning model pilotting was started in 10 schools (5 Elementary Schools, and 5 Junior High Schools) spread in 5 provinces. The focus of this study is how the schools in 3TP areas - with their limited capacity - can initiate an ICTintegrated learning model. The objective is to describe how 
teachers in the schools of 3TP areas conduct ICTintegrated learning model pilloting. The result of this study is that the teachers firstly learn and map the digital learning content available, integrate them in their Teaching Action Plan (RPP), condition the students to learn the contents that will be discussed in the class, apply the ICT-integrated learning model, and finally evaluate the whole implementation process to improve it.

Keywords: Information and Communication Technology (ICT); frontier, outer, left, and border (3TP) areas; learning.

\section{PENDAHULUAN}

Dewasa ini, perkembangan/kemajuan teknologi informasi dan komunikasi (TIK) sangat pesat dan tiada seorang pun yang dapat memungkiri bahwa kemajuan TIK secara bertahap telah pula memengaruhi berbagai bidang tanpa terkecuali bidang pendidikan/ pembelajaran (Ariani, 2009; Siahaan, 2010). Secara teoritis, peran TIK dalam pembelajaran harus memungkinkan terjadinya proses belajar aktif di mana peserta didik terlibat aktif dalam proses belajar yang menarik dan bermakna sehingga berkembang aktivitas belajar secara mandiri pada diri peserta didik (Wahyu, Muladi dan Mizar, 2016) sehingga mempermudah guru dan peserta didik di dalam aktivitas pembelajaran (Warsihna, 2013). Oleh karena itu, lembaga-lembaga pendidikan formal dan non-formal serta lembaga-lembaga pelatihan juga telah merasakan adanya peningkatan tuntutan/kebutuhan akan penerapan TIK dalam kegiatan pendidikan/pembelajaran (Siahaan, 2010).

Istilah Teknologi Informasi dan Komunikasi muncul pada abad ke-20 setelah adanya perpaduan antara teknologi komputer dengan teknologi komunikasi pada pertengahan. Istilah teknologi informasi dan komunikasi mengandung pengertian yang luas yaitu segala kegiatan yang terkait dengan pemrosesan, manipulasi, pengelolaan, pemindahan informasi antarmedia (https:// id. wikipedia.org/ wiki/Teknologi_informasi_komunikasi) (Diakses tanggal 13 Agustus 2018).

Seiring dengan pesatnya perkembangan
TIK, maka kehidupan masyarakat juga mengalami perkembangan atau perubahan. Dikemukakan Bambang Warsita bahwa dewasa ini, masyarakat dunia berada di era informasi sehingga kehidupan masyarakatnya juga berkembang menjadi masyarakat berbasis pengetahuan (knowledge-based society) (Warsita, 2011).

Manakala kita mencermati manfaat dari perkembangan/kemajuan TIK dalam kehidupan sehari-hari, maka dapatlah dikatakan bahwa masyarakat luas telah merasakannya. Salah satu contohnya adalah kemudahan berkomunikasi dengan sanak saudara yang tinggal sangat jauh atau mungkin juga berada di negara tetangga. Sebelumnya, komunikasi yang demikian ini masih relatif sulit dirasakan masyarakat luas. Dalam konteks yang sedemikian ini, pengertian TIK masih sebatas sebagai wahana komunikasi yang berupa telepon genggam/seluler. Perangkat TIK yang berupa telepon genggam tidak lagi hanya menjadi dominasi masyarakat perkotaan saja tetapi secara bertahap sudah memengaruhi kehidupan masyarakat perdesaan (rural community).

Dalam perkembangannya, TIK tampaknya sudah cenderung menjadi salah satu tuntutan kebutuhan hidup sehari-hari masyarakat luas. Tidak hanya di kalangan mereka yang berstatus sebagai pejabat pemerintahan, pengusaha, profesional, siswa/mahasiswa, dan pegawai, tetapi juga para petugas kebersihan, tukang parkir, pedagang asongan, tukang sayur keliling, dan para pembantu rumah tangga. 
Apabila dicermati lebih jauh lagi, hampir seluruh lapisan masyarakat dalam kehidupan sehari-harinya sudah tampak akrab dengan TIK sebagai wahana komunikasi. Bahkan dapat dikatakan bahwa kepemilikan dan penggunaan TIK tidak lagi hanya sebatas sebagai simbol prestise sosial saja tetapi lebih daripada itu, yaitu sudah cenderung dirasakan sebagai salah satu tuntutan kebutuhan hidup sehari-hari.

Demikian juga halnya dengan perangkat TIK yang berupa komputer dan internet. Pada awalnya memang, instansi pemerintah dan perusahaan yang sangat banyak memanfaatkan teknologi komputer dan internet. Namun perkembangan yang terjadi dewasa ini adalah bahwa komputer dan internet tidak hanya terbatas memasuki lembaga-lembaga pendidikan, pelatihan, tetapi juga sudah masuk ke rumah-rumah.

Jika semula masyarakat hanya dapat mengakses internet secara terbatas melalui kios atau warung internet, namun sekarang sudah semakin banyak anggota masyarakat yang mengakses internet dari rumahnya atau bahkan dari mana saja melalui gawai (handphone atau HP) yang dimiliki. Keadaan yang demikian ini merupakan pertanda bahwa masyarakat juga tampaknya terus mengikuti perkembangan atau kemajuan di bidang TIK.

Memperhatikan kemajuan teknologi komputer dan internet yang sangat pesat, ada kecenderungan baru yang mulai berkembang di kalangan sebagian para ibu rumah tangga tentang "kegiatan ngegossip/ngerumpi". Kegiatan ngegossip/ngerumpi ini biasanya dilakukan sebagian di kalangan para ibu secara tatap muka sewaktu mereka kumpulkumpul. Kegiatan ngerumpi para ibu ini telah ikut pula mengalami perkembangan/ perubahan. Para ibu tidak lagi harus berangkat meninggalkan rumah dan berkumpul secara fisik di suatu tempat untuk dapat ngerumpi. Kemajuan TIK telah memungkinkan para ibu tetap dapat ngerumpi sekalipun tinggal di rumahnya masingmasing. Kegiatan ngerumpi telah mengalami perubahan bentuk, tidak lagi dilakukan secara tatap muka tetapi dilakukan melalui dunia maya, baik melalui fasilitas "Facebook (FB)" maupun WhatsApp (WA).
Dalam berbagai pertemuan sosialkemasyarakatan, baik yang berupa arisan keluarga atau arisan di lingkungan komplek perumahan, salah satu topik yang mulai cenderung tidak ketinggalan dibicarakan para ibu rumah tangga adalah pengalaman mereka "berfeisbuk ria" (istilah "facebook" dituliskan dengan "feisbukan").

Selanjutnya, apabila kita mengamati aktivitas kehidupan sehari-hari, tampaklah bahwa anak-anak juga tidak mau ketinggalan dengan kemajuan TIK. Sebagai contoh misalnya, kita masuk ke dalam sebuah warung atau kiosk internet yang ada, apa yang kita amati atau lihat di dalamnya?

Pertama, yang tampak kepada kita adalah bahwa sebagian besar pengunjung dan pengguna jasa internet yang berada di dalam warung atau kiosk internet adalah anak-anak, remaja atau anak tanggung, para pemuda, baik yang masih bersekolah maupun yang tidak. Kedua, para pengunjung atau pengguna jasa internet ini tampak sebagian tekun mencari berbagai sumber belajar melalui fasilitas browsing/searching. Namun sebagian lagi di antara mereka tampak dipenuhi rasa gembira dan sekali-kali berteriak keras dan lepas sebagai cerminan betapa senang dan asyiknya mereka menikmati "online game".

Sebagai kesimpulan dapatlah dikatakan bahwa warung-warung atau kios internet yang tumbuh subur di tengah-tengah lingkungan masyarakat, mayoritas pengunjungnya pada umumnya adalah para remaja, siswa, dan mahasiswa. Mereka ini tampak menikmati kemajuan teknologi komputer dan internet karena mereka dapat bersenda gurau, berbagi pengalaman dan perasaan, berbagi informasi mengenai berbagai kejadian/ peristiwa yang terjadi, atau berdiskusi tentang tugas-tugas sekolah (pelajaran).

Interaksi atau komunikasi lewat teknologi internet tidak hanya terbatas antara sesama teman tetapi juga dengan orang lain yang mereka kenal melalui dunia maya. Dalam bingkai penggunaan TIK yang sedemikian ini, dapatlah dikatakan bahwa kemajuan teknologi komputer dan internet berfungsi positif dalam arti memberikan manfaat bagi penggunanya. Sebagai contoh manfaat TIK bagi penggunanya adalah bertambahnya 
khasanah pengetahuan, wawasan yang bertambah luas, mengetahui perkembangan berbagai kejadian/peristiwa mutakhir yang terjadi akhir-akhir ini di berbagai belahan dunia.

Jika kemajuan teknologi dibawa ke dalam ruang kelas dan dikelola dengan baik, akan mendorong peningkatan sumber daya dan mencipta inovasi dalam dunia pendidikan/ pembelajaran (Munawir A., dkk., 2016). Oleh karena itu, perlu dilakukan pembudayaan TIK di sekolah dan masyarakat secara bertahap, variatif, dan berkelanjutan melalui pengembangan SDM TIK secara terintegrasi (Pustekkom, 2011). Pembudayaan TIK di sekolah hendaknya memperhatikan kebutuhan, permasalahan dan potensi sekolah, sehingga pemanfaatan TIK dapat lebih efektif dan optimal. Namun yang menjadi pertanyaan adalah bagaimana para guru menghadirkan kemajuan teknologi dengan kandungan berbagai informasi atau konten pembelajaran yang dibutuhkan peserta didik ke dalam ruang kelas? (Anwas, 2011)

Salah satu caranya adalah melalui pemanfaatan TIK. Jika dilakukan melalui pemanfaatan TIK, apakah para guru sudah memiliki kesiapan pengetahuan dan keterampilan di bidang pengoperasian perangkat TIK? Tentu, sebelum memanfaatkan TIK dalam membelajarkan peserta didiknya, guru terlebih dahulu dituntut untuk membelajarkan dirinya sendiri.

Setelah familiar dengan perangkat TIK yang akan dimanfaatkan, barulah guru menggunakannya untuk membelajarkan peserta didiknya. Namun belumlah cukup jika guru hanya memiliki kemampuan sebatas mengoperasikan perangkat TIK saja. Guru hendaknya juga memiliki kemampuan untuk mengembangkan atau setidaknya mencari (browsing atau searching) berbagai konten pembelajaran yang dibutuhkan peserta didiknya guna mencapai kompetensi yang ditentukan.

Seandainya tuntutan kemampuan atau keterampilan guru di bidang pengoperasian perangkat TIK dan pengembangan atau pengemasan konten pembelajaran sudah terpenuhi melalui pelatihan misalnya, maka masalah berikutnya adalah mengenai ketersediaan perangkat TIK itu sendiri di sekolah. Masalah ketersediaan perangkat TIK di sekolah merupakan tugas dan tanggung jawab para pembuat kebijakan, baik di tingkat pusat, provinsi maupun Kabupaten/Kota.

Memiliki kemampuan atau keterampilan mengoperasikan perangkat TIK dan pengemasan konten pembelajaran seperti yang dikemukakan di atas bagi sebagian besar para guru di daerah perkotaan kemungkinan tidaklah terlalu menjadi masalah. Kondisinya tentu akan sangat jauh berbeda dengan para guru yang berada dan bertugas di daerah nun jauh di sana, di daerah terdepan, terluar, tertinggal, dan perbatasan (3TP). Berdasarkan survei pendahuluan yang dilakukan Pustekkom, kondisi sekolah-sekolah di daerah 3TP pada umumnya tidak hanya menghadapi kendala infrastruktur yang tidak tersedia tetapi sumber daya manusianya (SDM) juga belum siap di samping ketersediaan konten pembelajaran digital dan dukungan kebijakan (Pustekkom, 2012a).

Selain beberapa kendala yang telah dikemukakan, masih ada beberapa kendala lainnya yang diidentifikasi UNESCO yang dihadapi sekolah-sekolah di Indonesia sebagai negara berkembang, yaitu (1) ketersediaan sumber daya tenaga listrik, (2) ketersediaan jaringan telekomunikasi, (3) belum memadainya ketersediaan tenaga yang mampu mengelola peralatan, (4) masih relatif tingginya biaya akses internet di sebagian besar wilayah Indonesia, dan (5) kurangnya sumber-sumber belajar digital berbahasa Indonesia (UNESCO, 2013).

Kendala atau kondisi yang diidentifikasi dihadapi sekolah-sekolah sebagaimana yang telah dikemukakan diperkuat lagi oleh hasil survei pendahuluan yang dilakukan Pustekkom tentang kondisi sekolah-sekolah di daerah 3TP. Hasil survei mengemukakan bahwa sebagian besar sekolah di daerah 3TP tidak memiliki (1) sumber daya tenaga listrik, (2) akses internet, (3) infrastruktur TIK, (4) SDM yang terampil di bidang TIK; dan (5) sinyal telepon seluler walaupun di beberapa lokasi ada, sinyalnya lemah (Pustekkom, 2012a). 
Kondisi yang pada umumnya terjadi di sekolah-sekolah di daerah 3TP sebagaimana yang dikemukakan di atas direspons secara positif dalam bentuk aksi oleh Pusat Teknologi Informasi dan Komunikasi Pendidikan dan Kebudayaan-Kementerian Pendidikan dan Kebudayaan (PustekkomKemendikbud). Sesuai dengan kondisi yang ada, Pustekkom melakukan penelitian lanjutan yaitu tentang pemilihan dan penentuan daerah dan sekolah untuk dijadikan sebagai tahap awal perintisan pemanfaatan TIK untuk pembelajaran.

Laporan hasil penelitian lanjutan merekomendasikan 5 lokasi untuk ditetapkan sebagai tempat perintisan penerapan model pembelajaran terintegrasi TIK, yaitu (1) Lebak-Banten, (2) Cianjur-Jawa Barat, (3) Nunukan-Kalimantan Timur, (4) SangiheSulawesi Utara, dan (5) Belu-Nusa Tenggara Timur). Pada masing-masing lokasi dipilih 2 sekolah (1 SD/MI dan 1 SMP/MTs) yang diutamakan adalah yang tidak (1) mempunyai sumber daya tenaga listrik, (2) mempunyai fasilitas pendukung (antena parabola) untuk mengikuti program pembelajaran yang ditayangkan melalui Siaran Televisi Edukasi (TVE), (3) dapat memanfaatkan akses internet, dan (4) memiliki fasilitas laptop dan $\angle C D$ projector untuk kegiatan pembelajaran (Siahaan, 2013).

Kemudian, para guru yang mengajar di sepuluh sekolah yang telah ditetapkan sebagai tempat perintisan pemanfaatan TIK dalam pembelajaran dipersiapkan dan dibimbing oleh tim Pustekkom. Pembimbingan dilakukan melalui pelatihan dan pendampingan sehingga para guru dapat merancang dan melaksanakan sendiri kegiatan pembelajaran yang terintegrasi TIK (Pustekkom, 2012b). Selanjutnya, masingmasing guru ini diharapkan akan dapat mengembangkan kreativitas mereka sendiri dalam membelajarkan peserta didiknya melalui penerapan model pembelajaran yang terintegrasi TIK.

Model pembelajaran yang telah dirintis Pustekkom di 5 lokasi daerah 3TP yang tersebar di 5 provinsi direplikasi oleh beberapa kabupaten lainnya yang memiliki daerah yang termasuk pada kategori daerah 3TP. Di samping itu, kegiatan replikasi model pembelajaran terintegrasi TIK ini dilakukan juga oleh Pustekkom untuk diterapkan di daerah-daerah 3TP lainnya melalui kerjasama dengan Kementerian Komunikasi dan Informatika. Masalahnya adalah bagaimana sekolah-sekolah di daerah 3TP yang semula tidak memiliki (1) sumber daya tenaga listrik, (2) koneksi internet, (3) perangkat TIK, dan (4) konten pembelajaran digital; dan para guru yang jumlahnya terbatas, juga belum familiar dan siap dengan perangkat TIK telah mengalami perubahan sehingga mereka dapat menyelenggarakan kegiatan pembelajaran melalui pemanfaatan TIK.

\section{METODA}

Tulisan ini merupakan hasil studi atau kajian literatur yang mengkaji berbagai literatur atau bahan pustaka, baik yang berupa laporan hasil-hasil (penelitian penjajagan dan penelitian kelayakan, sosialisasi pengenalan TIK dalam kegiatan pembelajaran, pelatihan pemanfaatan TIK untuk pembelajaran, pembinaan atau bimbingan teknis pemanfaatan TIK, dan laporan pelaksanaan kegiatan) maupun yang berupa artikel yang dipublikasikan melalui jurnal ilmiah dan media jaringan. Kemudian, hasil telaah/analisis terhadap berbagai dokumen yang dapat diperoleh disajikan penulis secara deskriptif dalam bentuk sebuah artikel.

\section{HASIL DAN PEMBAHASAN}

\section{Guru, Kemajuan TIK, dan Pembelajaran}

Kemajuan TIK tampaknya tidak hanya memengaruhi pola hidup sehari-hari para orang dewasa tetapi juga pola hidup hampir semua orang dari semua usia. Tidak terkecuali dengan guru karena melalui pemanfaatan TIK, suasana pembelajaran, metode dan strategi pembelajaran, serta peran guru mengalami perubahan yang signifikan (Kwartolo, 2010). Namun terhadap kemajuan TIK ini, baru sebagian guru yang meresponsnya secara positif. Bahkan lebih jauh lagi, sebagian di antara para guru yang merespon secara positif kemajuan TIK ini 
telah tergugah pula untuk mempelajari dan kemudian memanfaatkannya untuk kepentingan kegiatan pembelajaran peserta didiknya. Artinya, kemajuan TIK sangat dirasakan benar manfaatnya oleh guru. Bahkan ada sebagian di antara para guru yang merasakan bahwa diri mereka tidak dapat terlepas dari TIK, mulai dari saat bangun pagi sampai dengan beristrahat tidur pada malam hari.

Bagaimana dengan sebagian guru lainnya? Tentulah tidak diragukan lagi bahwa mereka juga pastilah mengikuti atau setidaktidaknya mengetahui perkembangan atau kemajuan TIK disertai berbagai manfaatnya; tetapi mengapa ada sebagian di antara para guru ini yang belum memanfaatkannya dalam pelaksanaan tugas profesional sehari-hari mereka membelajarkan peserta didiknya? Kondisi yang demikian ini menjadi sesuatu yang menarik untuk dikaji. Dikatakan menarik untuk dikaji karena apabila kepada guru ditanyakan tentang apa saja manfaat TIK, maka mereka akan menuturkan banyak manfaatnya sesuai dengan pengalaman hidup keseharian mereka.

Sementara sebagian guru lainnya, sekalipun telah mendengar informasi tentang kemajuan TIK (baik melalui sosialisasi maupun media lainnya) dan bahkan kemungkinan juga telah menggunakannya untuk kepentingan pribadi di dalam kehidupannya sehari-hari, namun mereka ini masih saja belum tergugah untuk memanfaatkannya dalam membelajarkan peserta didiknya. Kelompok guru ini masih saja lebih cenderung menggunakan metode pembelajaran yang bersifat konvensional dalam membelajarkan peserta didiknya, yaitu yang hanya mengandalkan kemampuan dirinya dengan penggunaan metode ceramah dan mencatat (talk and chalk).

Jika guru telah menyadari bahwa TIK sangat bermanfaat di dalam kehidupan mereka sehari-hari, maka tentulah akan berbeda jawaban atau respons mereka ketika ditanyakan tentang bagaimana kemungkinan mereka memanfaatkan TIK dalam membelajarkan peserta didik mereka. Tentunya para guru ini juga diharapkan akan tergugah untuk memanfaatkan kemajuan TIK dalam kegiatan pembelajaran yang mereka kelola setiap hari.

Jika seandainya pemanfaatan TIK yang dilakukan guru masih hanya sebatas untuk kepentingan diri pribadi mereka alias belum diterapkan di dalam kelas, tentu menjadi sesuatu yang menarik untuk diungkap lebih jauh apa yang menjadi pokok permasalahannya. Kemungkinan saja faktor penyebabnya dapat berupa (1) lingkungan sekolah yang kurang atau tidak kondusif terhadap pemanfaatan TIK, dan (2) tidak adanya dukungan kebijakan dari Kepala Sekolah, atau justru para guru sendiri yang menganggap pemanfaatan TIK dalam pembelajaran sebagai tugas tambahan.

\section{Faktor-faktor Penyebab Guru Memanfaatkan TIK atau Belum dalam Pembelajaran}

Manakala ada sekelompok guru yang secara teratur setiap harinya memanfaatkan TIK dalam membelajarkan peserta didiknya dan di sisi lain, ada sekelompok guru lainnya yang masih belum memanfaatkan TIK, tentulah ada faktor-faktor penyebabnya. Pertanyaannya adalah faktor-faktor apa saja yang kemungkinan menjadi penyebab guru merasa tergugah atau belum memanfaatkan TIK dalam membelajarkan peserta didiknya? Mengapa para guru yang sudah merespons kemajuan TIK secara positif dan bahkan sudah memanfaatkannya demi kepentingan dirinya sendiri tetapi belum juga tergugah untuk memanfaatkannya bagi kepentingan pembelajaran peserta didiknya?

Tampaknya sangat menarik untuk mengkaji/menelaah lebih jauh tentang berbagai faktor yang kemungkinan dapat memengaruhi guru sehingga belum atau kurang tergugah untuk memanfaatkan TIK dalam membelajarkan peserta didiknya atau juga sebaliknya. Melalui pembahasan tentang faktor-faktor penyebab guru tergugah atau bahkan belum/kurang tergugah memanfaatkan kemajuan TIK dalam membelajarkan peserta didiknya, diharapkan akan dapat mempercepat upaya penyebarluasan model pembelajaran terintegrasi TIK di daerah 3TP lainnya. 
Memang sebagian para guru di daerah 3TP ini memiliki perangkat TIK yang berupa telepon seluler/genggam, tetapi mereka tidak dapat memanfaatkannya alias perangkatnya tidak dapat berfungsi selama mereka berada di lokasi sekolah karena tidak ada signal. Jika sekalipun ada signal, signalnya lemah yang juga kadang-kadang ada dan kadang-kadang juga hilang. Perangkat telepon genggam yang dimiliki sebagian guru barulah berfungsi setelah mereka berada di rumah mereka atau di daerah yang dekat dengan ibukota kecamatan atau kabupaten.

Secara garis besar, ada 2 faktor utama yang menurut pendapat penulis yang dapat memengaruhi guru sehingga belum atau kurang tergugah untuk memanfaatkan TIK dalam membelajarkan peserta didiknya, yaitu sebagai berikut.

Pertama, faktor yang berasal dari dalam diri guru sendiri (internal), yaitu yang antara lain mencakup:

- masih terbatasnya pengetahuan dan kemampuan guru di bidang pemanfaatan perangkat TIK untuk kepentingan pembelajaran peserta didiknya (familiaritas atau keakraban terhadap perangkat TIK);

- belum berkembangnya inisiatif guru untuk melakukan pengembangan potensi dirinya di bidang pemanfaatan TIK (upaya pengembangan potensi diri);

- belum terkondisikannya guru untuk berinisiatif mencoba menerapkan upaya atau gagasan pembaharuan di bidang pembelajaran (kemauan berinovasi); dan

- belum berkembangnya motivasi guru untuk memulai model pembelajaran terintegrasi TIK (pemanfaatan TIK dianggap sebagai tambahan beban kerja guru).

Penerapan kegiatan pembelajaran melalui pemanfaatan TIK sangat berkaitan erat dengan pengetahuan dan kemampuan guru di bidang pengunaan/pengoperasian perangkat TIK. Secara umum, tampaknya pengalaman guru yang berkaitan dengan TIK dirasakan masih memprihatinkan. Sebagai contoh adalah pada saat dilaksanakannya Uji Kompetensi Awal Guru (UKAG) pada tahun
2012. Pada tahap awal, hasil Uji Kompetensi Guru (UKG) mengungkapkan bahwa para guru yang mencapai nilai rerata $(42,25)$ adalah di Provinsi DKI Jakarta $(49,2)$, Bali $(48,9)$, Jawa Timur $(47,1)$, Jawa Tengah $(45,2)$, Jawa Barat $(44,0)$, Kepulauan Riau $(43,8)$, dan Sumatera Barat $(42,7)$ (http://www. sekolahdasar.net/2012/03/pengumumanhasil-uji-kompetensi-awal.html). Hasil UKAG ini mengungkapkan bahwa sebagian besar provinsi hanya mencapai atau berada di bawah nilai rerata 42,25 .

Pada dasarnya, pelaksanaan UKG menurut Syawal Gultom adalah bertujuan untuk pemetaan kompetensi guru yang akan digunakan sebagai ladasan kegiatan pengembangan keprofesian berkelanjutan (continuing professional development). UKG juga sekaligus dijadikan sebagai bagian dari proses penilaian kinerja guru untuk mendapatkan gambaran yang utuh terhadap pelaksanaan semua standar kompetensi (Gultom, 2013).

Berkaitan erat dengan hasil UKG yang relatif rendah, diduga salah satu penyebabnya adalah belum terbiasanya guru menggunakan/mengoperasikan perangkat komputer dan internet. Kondisi yang demikian ini didukung oleh pernyataan pejabat Dinas Pendidikan kabupaten tertentu mengenai kondisi guru di wilayah kerjanya. Dikemukakan bahwa di wilayah kerjanya terdapat sekitar $90 \%$ guru SD dan $85 \%$ guru SMP yang sama sekali tidak dapat mengoperasikan perangkat komputer.

Pernyataan pejabat Dinas Pendidikan kabupaten tersebut di atas dikemukakan secara lisan kepada tim nara sumber Pustekkom pada saat Pustekkom menyelenggarakan pelatihan pemanfaatan TIK untuk pembelajaran di tingkat kabupaten pada tahun 2014. Kondisi yang memprihatinkan inilah yang kemungkinan dijadikan sebagai salah satu dasar pertimbangan menunjuk kabupaten tertentu sebagai tempat penyelenggaraan pelatihan tentang pemanfaatan TIK untuk pembelajaran.

Di samping belum terbiasanya guru menggunakan komputer, faktor lain yang kemungkinan juga berpengaruh adalah (1) 
sikap guru yang belum kondusif terhadap pemanfaatan kemajuan TIK untuk kepentingan pembelajaran, (2) sikap guru yang tidak mau repot-repot menambah kesibukan dirinya untuk memanfaatkan TIK dalam membelajarkan peserta didiknya, dan (3) sikap guru yang enggan memanfaatkan TIK dalam membelajarkan peserta didiknya jika tidak atau belum jelas apa keuntungan yang akan mereka peroleh.

Di beberapa provinsi dan kabupaten/kota, masing-masing guru dikondisikan agar secara swadana dan bertahap berusaha untuk memiliki sebuah laptop. Dengan kondisi yang diciptakan sedemikian ini, para guru mau-tidakmau akan berupaya, tidak hanya untuk memiliki laptop tetapi juga akan belajar tentang caracara untuk mengoperasikannya. Manakala pengetahuan dan kemampuan/keterampilan guru telah cukup memadai di bidang pemanfaatan TIK untuk pembelajaran dan juga didukung oleh sikap guru yang selalu responsif terhadap berbagai upaya pembaharuan, maka dapat diyakini akan terbuka jalan kearah keterlaksanaan pemanfaatan TIK secara terpadu dalam kegiatan pembelajaran.

Sebaliknya juga dapat terjadi bahwa kemajuan TIK tidak berdampak positif tetapi justru negatif karena tidak dimanfaatkan secara arif dan bertanggungjawab. Tidak sedikit peserta didik yang "terlena dengan keasyikan ber-game online" yang mereka nikmati melalui kemajuan teknologi komputer dan internet. Sebagai akibatnya, mereka yang masih berstatus pelajar atau mahasiswa ini menjadi terlena dan lupa makan, lupa mengerjakan tugas sehari-harinya, dan bahkan pada akhirnya mulai timbul perasaan malas, baik untuk belajar maupun pergi ke kampus atau ke sekolah secara teratur. Jika keadaan yang demikian ini terjadi dan berlanjut secara terusmenerus, maka pada akhirnya akan merugikan diri peserta didik sendiri. Oleh karena itu, dapatlah dikatakan bahwa kemajuan TIK akan berdampak positif atau negatif, sangat ditentukan atau tergantung pada manusia (baca: guru) yang memanfaatkannya.

Perkembangan atau kemajuan TIK yang sedemikian pesatnya telah memengaruhi sebagian besar aspek kehidupan manusia pada umumnya, memudahkan berbagai aktivitas pekerjaan dan kehidupan (Sihabudin, 2013), dan secara khusus di bidang pembelajaran menuntut perubahan peran atau tugas guru dalam membelajarkan peserta didiknya. Melalui pemanfaatan kemajuan TIK akan memungkinkan terjadinya proses belajar yang antara lain bersifat aktif, konstruktif, kolaboratif, antusiastik, dialogis, reflektif (Chaeruman, 2008).

Lebih jauh, Sodiq Anshori mengemukakan bahwa pemanfaatan TIK (1) tidak hanya memberikan pengaruh yang cukup bermakna terhadap proses dan hasil pembelajaran di dalam kelas tetapi juga di luar kelas, (2) memungkinkan terjadinya individualisasi, akselerasi, pengayaan, perluasan, efektivitas dan produktivitas pembelajaran yang pada gilirannya akan meningkatkan kualitas pendidikan, (3) memotivasi/merangsang peserta didik untuk belajar maju berkelanjutan sesuai dengan potensi dan kecakapan yang mereka miliki, dan (4) menuntut kreativitas dan kemandirian peserta didik sehingga memungkinkan pengembangan semua potensi yang mereka miliki (Anshori, 2018).

Dengan berkembangnya proses belajar sebagaimana yang dikemukakan Chaeruman, maka dampak lebih jauh adalah mengarah pada keberhasilan pembelajaran. Dikatakan demikian karena TIK memiliki berbagai potensi atau kelebihan, seperti: (1) membantu guru menyajikan materi pembelajaran menjadi lebih mudah dan cepat (Rahim, 2011), (2) membantu mempermudah peserta didik memahami materi pelajaran, (3) materi pelajaran lama diingat dan mudah diungkapkan kembali, dan (4) menarik dan membangkitkan perhatian, minat, motivasi, aktivitas, dan kreativitas belajar peserta didik (Munir, 2010). Potensi TIK yang demikian ini apabila dimanfaatkan secara arif dan bertanggung jawab akan meningkatkan efektivitas dalam pelaksanaan proses pembelajaran yang pada akhirnya diharapkan dapat meningkatkan hasil belajar siswa dan mutu individu para peserta didik (Husain, 2014).

Seiring dengan potensi atau kelebihan kemajuan TIK dan dampak pemanfaatannya dalam kegiatan pembelajaran, ada satu 
pertanyaan yang menarik untuk diperbincangkan, yaitu bagaimana respons guru atau bagaimana guru merespons kemajuan TIK dalam pelaksanaan tugas profesinya (kegiatan belajar-mengajar) sehari-hari?

Dalam merespons kemajuan TIK, apakah para guru (1) telah memperlihatkan respons yang positif dan juga berinisiatif memanfaatkannya dalam kegiatan pembelajaran sesuai dengan pengetahuan dan kemampuan yang dimilikinya, (2) merasa cukup puas dengan kondisi keberadaannya yang sekarang ini dan tidak mau "direpotkan" dengan kemajuan TIK yang terjadi, (3) menyerahkan pemanfaatan TIK untuk kepentingan kegiatan pembelajaran kepada para guru yang lebih muda (guru junior), atau (4) menunggu saja sampai fasilitas TIK tersedia di sekolah dan pimpinan sekolah menugaskan mereka untuk mengikuti kegiatan pelatihan/ penataran di bidang pemanfaatan TIK untuk kepentingan pembelajaran?

Dengan mencermati atau menelaah serangkaian pertanyaan tersebut di atas setidak-tidaknya diharapkan akan dapat menggugah pikiran dan perasaan guru, sesuai dengan kondisinya masing-masing, untuk berinisiatif memanfaatkan TIK dalam membelajarkan peserta didiknya. Melalui kebersamaan yang demikian ini dan juga didukung oleh keinginan untuk saling membelajarkan antara sesama guru serta saling berbagi pengalaman (best practices di bidang pemanfaatan TIK untuk pembelajaran), maka para guru telah berada kearah pelaksanaan kegiatan pembelajaran yang memanfaatkan TIK yang pada akhirnya diharapkan akan bermuara kearah keterlaksanaan pembelajaran yang terintegrasi dengan TIK.

Kedua, selain faktor internal yang berasal dari dalam diri guru, masih ada beberapa faktor lainnya yang berasal dari luar diri guru (eksternal), yaitu:

- ada-tidaknya dukungan kebijakan dari Dinas Pendidikan Kabupaten/Kota atau Kepala Sekolah di bidang pemanfaatan TIK untuk pembelajaran;

- ketersediaan fasilitas TIK dan perangkat pendukungnya di sekolah atau di dalam kelas yang memungkinkan guru sewaktu-waktu dapat memanfaatkannya untuk membelajarkan peserta didiknya;

- ketersediaan konten-konten pembelajaran dalam bentuk digital yang dapat dimanfaatkan melalui perangkat TIK yang tersedia di sekolah;

- ada-tidaknya penyelenggaraan pelatihan bagi guru secara berkala di bidang pemanfaatan TIK, baik mengenai perancangan dan pengembangan bahan-bahan belajar yang memanfaatkan TIK maupun strategi pembelajaran dengan pemanfaatan TIK; dan

- ada-tidaknya contoh sekolah terdekat yang dapat dikunjungi guru yang telah terbukti berhasil meningkatkan prestasi belajar peserta didiknya melalui pemanfaatan TIK dalam kegiatan pembelajaran.

\section{Guru Daerah 3TP dan Pemanfaatan TIK untuk Pembelajaran}

Sehubungan dengan upaya perintisan pemanfaatan TIK dalam kegiatan pembelajaran di sekolah-skeolah di daerah 3TP, hasil penelitian Sudirman Siahaan mengungkapkan bahwa (1) para guru sangat tergugah, termotivasi, dan bersemangat untuk mengoptimalkan pemanfaatan TIK bagi kepentingan belajar peserta didik mereka, dan juga (2) para orang tua peserta didik, tokoh masyarakat, dan pemangku kepentingan di bidang pendidikan juga sangat mendukung upaya perintisan pemanfaatan TIK dalam pembelajaran (Rivalina dan Siahaan, 2013).

Sebagian para guru yang mengajar di kedua sekolah yang menjadi lokasi perintisan pemanfaatan TIK untuk pembelajaran (khususnya yang mengajar di SDN dan SMPN di desa Sabulmil), harus tinggal di lingkungan atau kompleks sekolah. Pertimbangannya adalah karena jarak lokasi sekolah yang relatif jauh dan kondisi jalannya yang relatif sulit terlebih-lebih lagi pada musim penghujan. Dengan demikian, tidak efisien jika guru harus setiap hari berangkat dari rumah masingmasing ke sekolah tempat mereka mengajar. Para guru yang mengajar di sekolah-sekolah 
di daerah 3TP pada umumnya dan di wilayah Kabupaten Belu dan Sangihe pada khususnya mengungkapkan rasa keberuntungan mereka dapat berperanserta dalam membelajarkan peserta didik mereka melalui pemanfaatan TIK. Tidak ada di antara para guru ini yang pernah menduga apalagi membayangkan sebelumnya bahwa sekolah mereka yang kondisinya serba terbatas akan dimungkinkan untuk memulai kegiatan pembelajaran melalui pemanfaatan komputer yang terkoneksi dengan internet (blessing in disguise).

Sebagai informasi bahwa hampir semua guru yang terbatas jumlahnya yang mengajar di kedua sekolah perintisan yang tersebar di 5 provinsi belum pernah sebelumnya memanfaatkan TIK di dalam kegiatan pembelajaran. Alasannya sederhana yaitu tidak adanya sumber tenaga listrik dan perangkat TIK di sekolah di samping para guru sendiri belum pernah dilatih tentang pemanfaatan TIK dalam pembelajaran. Sekalipun demikian, mereka tidak menjadikan kondisi yang mereka hadapi tersebut sebagai kendala atau masalah; namun sebaliknya, dengan penuh semangat, mereka menerapkan model pembelajaran yang masih baru bagi mereka, yaitu yang terintegrasi TIK. Seiring dengan kemajuan TIK, Pusat Teknologi Informasi dan Komunikasi Pendidikan dan Kebudayaan-Kementerian Pedidikan dan Kebudayaan (PustekkomKemendikbud) telah mengembangkan berbagai program di bidang pemanfaatan TIK untuk kepentingan pendidikan/pembelajaran.

Erat kaitannya dengan pemanfaatan TIK untuk pembelajaran, dibutuhkan pengetahuan dan kemampuan guru di bidang penggunaan/ pengoperasian perangkat TIK. Tampaknya, pengalaman guru yang berkaitan dengan pemanfaatan TIK secara umum dirasakan masih memprihatinkan. Sebagai contoh bukti tentang kondisi yang demikian ini adalah pada saat dilaksanakannya Uji Kompetensi Guru (UKG) di semua provinsi pada tahun 2015 (http://gtk.kemdikbud.go.id/post/ujikompetensi-guru).

Mengingat masih belum memadainya atau masih memprihatinkannya pengetahuan dan kemampuan guru di bidang penggunaan/ pengoperasian perangkat TIK, maka Pustekkom secara teratur dan berkelanjutan menyelenggarakan pelatihan, baik di tingkat provinsi, kabupaten/kota maupun di tingkat sekolah. Penyelenggaraan pelatihan tidak hanya terbatas pada ketersediaan anggaran Pustekkom tetapi dapat juga didasarkan atas ketersediaan anggaran pemerintah daerah atau khususnya Dinas Pendidikan Kabupaten/ Kota.

Melalui kerjasama antara satuan kerja di lingkungan pemerintah pusat dengan yang ada di lingkungan pemerintah daerah diharapkan akan dapat mempercepat pemberdayaan (empowering) para guru dan tenaga kependidikan lainnya yang berada di daerah 3TP mengenai pemanfaatan TIK untuk membelajarkan peserta didik. Sebagai tindak lanjutnya, para guru dan tenaga kependidikan yang telah mengikuti kegiatan pelatihan diharapkan mengimbaskan pengetahuan dan keterampilan serta pengalaman yang telah mereka miliki (best practices) kepada sesama guru di sekolah-sekolah sekitarnya. Melalui kebersamaan yang demikian ini diharapkan akan dapat mempersempit kesenjangan (gap) kondisi yang terjadi, baik antara sekolahsekolah di daerah 3TP sendiri maupun dengan sekolah-sekolah di daerah perkotaan.

Pada akhirnya, upaya pemberdayaan para guru, tenaga kependidikan, dan peserta didik melalui pemanfaatan TIK secara terintegrasi dalam pembelajaran diharapkan akan bermuara kearah peningkatan kualitas pembelajaran. Dalam kaitan ini, hasil penelitian Andita Faizatul Bachrintania juga mengemukakan bahwa pemanfaatan TIK berpengaruh positif dan signifikan terhadap prestasi belajar siswa (Bachrintania, 2012).

Dalam rangka menuju kearah keterlaksanaan kegiatan pembelajaran terintegrasi TIK dituntut adanya upaya sinergis dari berbagai pihak, baik dari diri guru dan peserta didik sendiri maupun dari pemerintah (baik pusat maupun daerah) dan masyarakat sebagaimana yang diamanatkan oleh konstitusi. Berikut ini akan diuraikan berbagai upaya atau inisiatif (di luar pengadaan dan pemasangan prangkat TIK di sekolah) yang telah dilakukan yang dapat dijadikan sebagai langkah-langkah awal pemanfaatan TIK untuk 
kepentigan pembelajaran di daerah 3TP yang memerlukan tindak lanjut dan juga sekolahsekolah di daerah 3TP lainnya.

Pertama, pelatihan yang dikhususkan bagi para guru di bidang pemanfaatan TIK untuk pembelajaran di daerah 3TP. Pelatihan bagi para guru ini tidak hanya yang berkaitan dengan pengembangan konten pembelajaran berbasis TIK tetapi dapat juga yang berkaitan dengan pemanfaatan TIK secara terintegrasi dalam kegiatan pembelajaran di kelas. Dalam kaitan ini, Kementerian Pendidikan dan Kebudayaan melalui Pustekkom secara bertahap setiap tahunnya menyelenggarakan kegiatan pelatihan/penataran para guru. Pelatihan yang diselenggarakan secara teratur setiap tahunnya di masing-masing provinsi mencakup pemanfaatan TIK dalam kegiatan pembelajaran dan pengembangan konten pembelajaran berbasis TIK, mulai dari yang bersifat sederhana sampai dengan yang konten pembelajaran yang bersifat canggih. Diharapkan para guru dapat memanfaatkan peluang atau kesempatan yang ditawarkan setiap tahunnya ini.

Pelatihan para guru di bidang pemanfaatan TIK untuk pembelajaran ini tidak hanya atas inisiatif yang berasal dari Pustekkom tetapi juga berasal dari permintaan daerah (inisiatif daerah) dan sebagian lagi didasarkan atas kerjasama Pustekkom dengan beberapa dinas pendidikan kabupaten/kota. Di samping secara tatap muka (bagi pemula untuk pengetahuan dan kemampuan dasar), pelatihan TIK bagi para guru yang sudah terbiasa menggunakan komputer dan internet juga dilakukan melalui sistem belajar jarak jauh dengan menggunakan internet (portal Rumah Belajar).

Pelatihan secara singkat tentang pemanfaatan TIK untuk pembelajaran dapat juga diberikan kepada para guru. Sebagai contoh misalnya adalah pelatihan mengenai strategi pemanfaatan TIK secara terpadu dalam kegiatan pembelajaran. Tujuannya adalah untuk memberikan kemudahan kepada guru dalam melaksanakan kegiatan pembelajaran yang terintegrasi TIK. Di samping itu, para guru juga masih perlu dilatih tentang perancangan dan pengembangan konten-konten pembelajaran sehingga mereka dapat mengembangkan sendiri berbagai konten pembelajaran termasuk yang khas lokal atau daerah setempat.

Di samping membekali para guru dengan pengetahuan dan keterampilan pengembangan konten pembelajaran digital, Pustekkom juga memberikan berbagai konten pembelajaran digital yang telah dirancang dan dikembangkan Pustekkom sendiri sesuai dengan tuntutan kurikulum yang berlaku. Pada umumnya, pelatihan perancangan dan pengembangan konten pembelajaran berbasis TIK ini hanya diberikan kepada para guru yang bertugas di sekolah-sekolah yang telah memiliki perangkat komputer dan peralatan proyeksi.

Kedua, sekolah-sekolah yang terpilih sebagai sekolah yang berperanserta dalam perintisan pemanfaatan TIK secara terintegrasi untuk kepentingan kegiatan pembelajaran, dilengkapi dengan perangkat TIK yang dibutuhkan dan konten-konten pembelajaran digital sehingga perintisan model pembelajaran berbasis TIK dapat berjalan atau dilaksanakan. Kemudian, model pembelajaran berbasis TIK yang telah dirintis di 5 daerah 3TP direplikasi oleh beberapa pemerintah kabupaten (Dinas Pendidikan Kabupaten) yang mempunyai daerah 3TP disertai dengan pendampingan dari Pustekkom di dalam penerapannya. Model pembelajaran berbasis TIK ini juga diharapkan dapat diimbaskan ke berbagai sekolah yang berminat yang ada di lingkungan sekolah perintisan.

Ketiga, masing-masing guru mempelajari konten-konten pembelajaran digital yang diberikan Pustekkom sesuai dengan mata pelajaran yang diampu. Kemudian, masingmasing guru memetakan pemanfaatan berbagai konten pembelajaran untuk setiap pertemuan selama satu semester. Selanjutnya, untuk kepentingan simulasi pelaksanaan model pembelajaran terintegrasi TIK, setiap guru memilih konten pembelajaran yang akan dibahas atau didiskusikan dengan peserta didiknya. Kegiatan berikutnya adalah menyusun RPP yang terintegrasi TIK.

Keempat, menerapkan atau melaksanakan RPP terintegrasi TIK di dalam kelas (simulasi) yang didampingi oleh tim 
Pustekkom. Setelah selesai simulasi, tim Pustekkom mendiskusikan hasil pengamatan terhadap pelaksanaan simulasi yang dilakukan guru (atau pemberian umpan balik untuk penyempurnaan). Pada setiap penerapan model pembelajaran terintegrasi TIK harus diawali guru dengan terlebih dahulu menyusun RPP yang terintegrasi TIK dan kemudian diikuti dengan evaluasi keterlaksanaannya.

Upaya pemberdayaan guru di daerah 3TP di bidang penerapan model pembelajaran terintegrasi TIK merupakan dukungan terhadap kebijakan peberdayaan daerah dan masyarakat 3TP, khususnya di bidang pendidikan. Perintisan dan diseminasi model pembelajaran terintegrasi TIK tidak hanya dilaksanakan di sekolah-sekolah yang ada di daerah perkotaan tetapi lebih diutamakan di sekolah-sekolah yang memiliki berbagai keterbatasan terutama di daerah 3TP.

Kelima, seiring dengan adanya pemberian tunjangan sertifikasi guru, tentunya semakin memungkinkan bagi para guru secara perseorangan dan bertahap melengkapi dirinya dengan perangkat TIK. Dengan perangkat TIK yang dimiliki guru akan memfasilitasi dirinya melakukan perintisan pemanfaatan TIK secara terpadu dalam kegiatan pembelajaran yang menjadi tugas profesionalnya. Dengan perangkat TIK, terbuka peluang bagi guru untuk meningkatkan kemampuan profesionalnya. Hal ini dapat saja dilakukan, baik melalui berbagai sumber belajar yang dapat diakses secara bebas maupun melalui chatting atau layanan konsultasi akademik yang berkaitan dengan upaya berbagi pengalaman dan pengetahuan. Berbagai sumber pengetahuan tersedia di dunia maya yang terbuka bagi siapa saja untuk mengaksesnya sesuai dengan kebutuhannya.

Selain menyelenggarakan kegiatan pelatihan, Pustekkom-Kemendikbud juga melaksanakan kegiatan pemasyarakatan (sosialisasi) pemanfaatan TIK untuk kegiatan pembelajaran, dan secara bertahap juga melaksanakan perintisan model pembelajaran yang memanfaatkan TIK di berbagai sekolah di beberapa provinsi.

Melalui kegiatan pemasyarakatan pemanfaatan TIK dalam kegiatan pembelajaran, pelatihan pemanfaatan TIK untuk pembelajaran, dan perintisan modelmodel pembelajaran terintegrasi TIK di berbagai sekolah di berbagai provinsi, diharapkan akan dapat meningkatkan pengetahuan dan kemampuan serta memotivasi guru untuk memanfaatkan TIK dalam membelajarkan peserta didiknya.

Hanya guru yang kreatif dan penuh inisiatif yang selalu membuka diri terhadap berbagai kemajuan atau pembaharuan (inovasi) termasuk kemajuan di bidang TIK, yang akan tergugah untuk menggagas penerapan kemajuan TIK di dalam kelas. Namun di sisi lain, tidak dapat disangkal bahwa ada juga sebagian guru yang merasa dan berpendapat bahwa tugas sehari-hari mereka sudah cukup repot sehingga apabila diminta untuk memanfaatkan TIK dalam kegiatan pembelajaran dipandang sebagai tambahan beban atau kerepotan saja. Lebih jauh, kelompok guru ini mengemukakan bahwa sekalipun kegiatan pembelajaran yang mereka kelola selama ini tanpa memanfaatkan TIK, namun prestasi belajar peserta didik mereka tidaklah terlalu mengecewakan.

Menurut Oos M. Anwas (Anwas, 2011), pemanfaatan TIK di sekolah ditujukan untuk membantu mengatasi masalah-masalah pendidikan dan pembelajaran sesuai dengan karakteristik dan kelebihan TIK. Oleh karena itu, pemanfaatan TIK di sekolah tidak hanya sekedar menyediakan infrastruktur dan konten pembelajaran. Bahkan lebih jauh dikemukakan Oos bahwa masalah pendidikan ini terkait dengan mutu dan daya saing yang masih rendah, kesenjangan terutama di daerah pedesaan, dan daerah-daerah terpencil.

Agar para guru tergugah untuk berperanserta aktif memanfaatkan TIK bagi kepentingan kegiatan pembelajaran, maka diperlukan dukungan kebijakan dari pembuat kebijakan (policy makers) terutama di lingkungan pemerintah provinsi dan kabupaten tentang pemanfaatan TIK secara terpadu dalam pembelajaran. Di samping itu, para guru juga perlu dimotivasi tentang potensi TIK yang dapat memberikan 
kemudahan bagi mereka dalam membelajarkan peserta didik.

Kemudahan yang dapat diperoleh melalui pemanfaatan TIK dalam pembelajaran tidak hanya bagi guru dalam membelajarkan peserta didiknya tetapi juga bagi peserta didik dalam memahami materi pelajaran. Memotivasi guru dapat saja dilakukan melalui pelatihan di bidang pemanfaatan TIK yang dilanjutkan dengan kegiatan pembimbingan guru secara langsung, baik dalam perancangan dan pengembangan kontenkonten pembelajaran maupun dalam pemanfaatannya.

\section{SIMPULAN DAN SARAN}

\section{Simpulan}

Berdasarkan hasil studi literatur atau telaah/kajian yang telah dilakukan terhadap berbagai dokumen, baik yang berupa laporan hasil-hasil kegiatan, penelitian penjajagan dan penelitian lanjutan, maupun yang berupa artikel penelitian/kajian yang dipublikasikan melalui jurnal ilmiah dan media jaringan, maka dapat dikatakan bahwa perintisan penerapan model pembelajaran terintegrasi TIK dilakukan para guru di daerah 3TP secara optimal, sekalipun hasilnya belum optimal. Namun dengan penuh semangat dan motivasi yang tinggi, para guru memanfaatkan TIK dalam membelajarkan peserta didik mereka.

Para guru melaksanakan pemanfaatan TIK secara terintegrasi dalam pembelajaran dimulai dari (1) mempelajari dan memetakan konten pembelajaran digital yang tersedia untuk setiap pertemuan sesuai dengan mata pelajaran yang diampu, (2) menyusun RPP yang terintegrasi dengan konten-konten pembelajaran yang tersedia, (3) menginformasikan kepada peserta didik tentang materi pelajaran yang akan dibahas dalam pertemuan berikutnya (kesiapan peserta didik), (4) menyelenggarakan kegiatan pembelajaran sesuai dengan RPP yang disusun, dan (5) mengevaluasi keterlaksanaan kegiatan pembelajaran terintegrasi TIK.

Saran

Sekolah-sekolah yang berada di daerah 3TP yang berperanserta dalam perintisan pemanfaatan TIK dalam kegiatan pembelajaran dapat melakukan hal yang sama ke sekolah-sekolah di sekitarnya melalui pembimbingan. Atau, sekolah-sekolah yang satu kecamatan atau di sekitar sekolah yang berperanserta dalam perintisan pemanfaatan TIK dalam kegiatan pembelajaran mempunyai tanggung jawab professional untuk berbagi pengetahuan, keterampilan, dan pengalaman mereka di bidang pemanfaatan TIK untuk pembelajaran ke berbagai sekolah-sekolah yang ada di sekitar wilayahnya. Pihak Pemerintah Daerah (Kabupaten dan Provinsi) perlu bekerjasama dengan berbagai instansi terkait (misalnya Kominfo setempat dan PustekkomKemendikbud) untuk mendukung percepatan penerapan pemanfaatan TIK dalam kegiatan pembelajaran di sekolah-sekolah lainnya di daerah 3TP.

\section{PUSTAKA ACUAN}

Buku

Munawir A. dkk. 2016. Inspirasi Pendidikan di Perbatasan: Menghadirkan Teknologi Informasi, Berjuang Melampaui Keterbatasan. Ciputat-Tangerang Selatan: Pusat Teknologi Informasi dan Komunikasi Pendidikan dan Kebudayaan-Kementerian Pendidikan dan Kebudayaan.

Munir. 2010. Kurikulum Berbasis Teknologi Informasi dan Komunikasi. Bandung: Alfabeta.

UNESCO Asia-Pacific Regional Bureau for Education APEID/ICT Education. 2013. ICT in Education, Policy, Infrastructure, and ODA Status in Selected ASEAN Countries. Bangkok: UNESCO Asia-Pacific Regional 429 Bureau for Education APEID/ICT Education. Sumber: http://www. unescobkk.org/ fileadmin/user_upload/ ict/ebooks/ICT_in_ Education_Policies_Infrastructure_and_ ODA.pdf (Diakses tanggal 09 September 2018). 
Jurnal/Prosiding/Disertasi/Tesis/Skripsi

Anshori, Sodiq. 2018. Pemanfaatan TIK Sebagai Sumber dan Media Pembelajaran di Sekolah, artikel dalam Jurnal IImu Pendidikan PKn dan Sosial Budaya Vol. 2 No. 1 (2018), Februari 2018. Bangkalan: Prodi PPKn STKIP PGRI Bangkalan.

Anwas, Oos M. 2011. Pembudayaan Teknologi Informasi dan Komunikasi di Sekolah, artikel di dalam Jurnal TEKNODIK Vol. 15 No.: 1, Juli 2011. Ciputat-Tangerang Selatan: Pusat Teknologi Informasi dan Komunikasi Pendidikan dan Kebudayaan-Kementerian Pendidikan dan Kebudayaan.

Ariani, Diana, 2009. Pembelajaran Berbasis TIK terhadap Orang Dewasa, artikel di dalam Jurnal TEKNODIK Vol. 13 No.: 1, Juli 2009. Ciputat-Tangerang Selatan: Pusat Teknologi Informasi dan Komunikasi Pendidikan dan Kebudayaan-Kementerian Pendidikan dan Kebudayaan.

Bachrintania, Andita Faizatul. 2012. "Pengaruh Pemanfaatan Teknologi Informasi dan Komunikasi (TIK) Dalam Pembelajaran Ekonomi Terhadap Motivasi dan Prestasi Belajar Ekonomi Siswa Kelas X di SMAN 3 Yogyakarta". Skripsi. Yogyakarta: Fakultas Ekonomi Universitas Negeri Yogyakarta.

Chaeruman, Uwes A. 2008. Mendorong Penerapan e-Learning di Sekolah, artikel dalam Jurnal TEKNODIK Vol. XII No.: 1, Juni 2008. Ciputat-Tangerang Selatan: Pusat Teknologi Informasi dan Komunikasi Pendidikan dan Kebudayaan-Kementerian Pendidikan dan Kebudayaan.

Husain, Chaidar. 2014. Pemanfaatan Teknologi Informasi dan Komunikasi dalam Pembelajaran di SMA Muhammadiyah Tarakan, artikel dalam Jurnal Kebijakan dan Pengembangan Pendidikan Volume 2, Nomor 2, Juli 2014. Malang: Universitas Muhammadiyah Malang.

Kwartolo, Yuli. 2010. Teknologi Informasi dan Komunikasi dalam Proses Pembelajaran, artikel dalam Jurnal Pendidikan PENABURNo. 14/Tahun ke-9/Juni 2010. Jakarta: Badan Pendidikan Kristen Penabur (BPK Penabur). Nur Hidayat, Wahyu, Muladi, dan Mizar, M. Alfian, 2016. Studi Integrasi TIK Dalam Pembelajaran Di Sekolah Menengah Kejuruan Pendidikan Kejuruan, artikel dalam Jurnal Pendidikan, Vol. 1, No. 12, Desember 2016, Malang: Pascasarjana Universitas Negeri Malang.

Rahim, H. Muhammad, Yusuf. 2011. Pemanfaatan

ICT Sebagai Media Pembelajaran Dan Informasi Pada UIN Alauddin Makassar, artikel dalam Jurnal Wawasan Keislaman Sulesana Volume 6 Nomor 2 Tahun 2011, Makassar: Fakultas Ushuluddin \& Filsafat UIN Alauddin Makassar.

Rivalina, Rahmi dan Siahaan, Sudirman. 2013. Tanggapan Awal terhadap Pemanfaatan TIK dalam Kegiatan Pembelajaran di Kabupaten Belu, artikel dalam Jurnal TEKNODIK Vol. 17 Nomor 4, Desember 2013. CiputatTangerang Selatan: PustekkomKemendikbud.

Siahaan, Sudirman. 2010. Jabatan Fungsional Pengembang Teknologi Pembelajaran (JFPTP): Apa dan Bagaimana?, artikel dalam Jurnal TEKNODIK Vol. 14 Nomor 1, Juni 2010. Ciputat-Tangerang Selatan: PustekkomKemendikbud.

Siahaan, Sudirman, 2013. Menuju Kearah Pendidikan Berkualitas di Daerah Tertinggal dan Perbatasan melalui Pemanfaatan TIK, artikel dalam Jurnal TEKNODIK Vol. 17 Nomor 1, Maret 2013. Ciputat-Tangerang Selatan: Pustekkom-Kemendikbud.

Siahaan, Sudirman. 2014. Pemanfaatan Teknologi Informasi dan Komunikasi (TIK) untuk Pembelajaran: Sebuah Kajian, artikel dalam Jurnal TEKNODIK Vol. 14 Nomor 1, Juni 2010. Ciputat-Tangerang Selatan: PustekkomKemendikbud.

Sihabudin, Ahmad. 2013. Teknologi Informasi Komunikasi dan Gaya Hidup Mahasiswa, artikel dalam Jurnal TEKNODIK Vol. 17 Nomor 2, Juni 2013. Ciputat-Tangerang 
Selatan: Pustekkom-Kemendikbud.

Warsihna, Jaka. 2013. Pemanfaatan Teknologi Informasi dan Komunikasi (TIK) untuk Pendidikan Daerah Terpencil, Tertinggal dan Terdepan (3T), artikel dalam Jurnal TEKNODIK Vol. 17, Nomor 2, Juni 2013. Ciputat-Tangerang Selatan: PustekkomKemendikbud.

Warsita, Bambang. 2011. Landasan Teori dan Teknologi Informasi dalam Pengembangan Teknologi Pembelajaran, artikel dalam Jurnal TEKNODIK Vol. 15 Nomor 1, Juli 2011. Ciputat-Tangerang Selatan: PustekkomKemendikbud.

\section{Lain-lain}

Kemdikbud. 2012. Laporan Hasil Monitoring dan

Evaluasi Pusat Sumber Belajar untuk Daerah Terpencil, Tertinggal, dan Terdepan. Tidak Dipublikasikan. Ciputat-Tangerang Selatan: Pustekkom-Kemendikbud.

Gultom, Syawal. 2013. Pengantar Pelaksanaan Uji Kompetensi Guru. BPSDMPK-PMP, Kementerian Pendidikan dan Kebudayaan. Jakarta: Kementerian Pendidikan dan Kebudayaan.

Pustekkom. 2012a. Laporan Kegiatan Pendampingan Layanan Pendidikan di Daerah Tertinggal, Terpencil, Terdepan dan Terdekat (4T) Marore, Kabupaten Sangihe. Tidak Dipublikasikan. Pusat Teknologi Informasi dan Komunikasi PendidikanKementerian Pendidikan dan Kebudayaan. Tangerang Selatan: Pusat Teknologi Informasi dan Komunikasi Pendidikan.

Pustekkom. 2012b. Laporan Kegiatan Pemanfaatan PSB 4T (Sebatik). Pelatihan Pemanfaatan Teknologi Informasi dan Komunikasi di Wilayah Tertinggal, Terpencil, Terdepan, dan Terdekat. Tidak Dipublikasikan. Tangerang Selatan: Pusat Teknologi Informasi dan Komunikasi Pendidikan-Kementerian Pendidikan dan Kebudayaan.
Website:https://id.wikipedia.org/wiki/ Teknologi_informasi_komunikasi (Diakses tanggal 13 Agustus 2018).

Website: Pengumuman Hasil Uji Kompetensi Awal Guru. Sumber:http://www.sekolah dasar.net/2012/03/pengumuman-hasil-ujikompetensi-awal.html (Diakses tanggal 17 September 2018).

Website: Uji Kompetensi Guru. Sumber: http:// gtk.kemdikbud.go.id/post/uji-kompetensiguru (Diakses tanggal 17 September 2018). 